\title{
Association between the duration of dominance of the ovulatory follicle and pregnancy rate in beef heifers
}

\author{
M. Mihm ${ }^{1}$, A. Baguisi ${ }^{2}$, M. P. Boland ${ }^{2}$ and J. F. Roche ${ }^{1}$ \\ ${ }^{1}$ Faculty of Veterinary Medicine, University College Dublin, Dublin, Ireland; and ${ }^{2}$ Faculty of Agriculture, \\ University College Dublin, Lyons Estate, Newcastle, Co. Dublin, Ireland
}

\begin{abstract}
After luteolysis, subluteal concentrations of progesterone or treatment with a synthetic progestagen result in an extended period of dominance (persistence) of the dominant follicle in cattle. Two experiments studied (I) the relationship between the duration of dominance of the ovulatory follicle and pregnancy rate and (2) the ability of a persistent dominant follicle to ovulate and form a normal functioning corpus luteum. In Expt 1, beef heifers were either untreated $(n=30)$ or given a synthetic progestagen implant ( 3 mg norgestomet) for 12 days starting on day 16 of their cycle $(n=32)$. The mean duration of dominance of the ovulatory follicle differed $(P<0.05)$ between treated and control heifers ( $10.8 \pm 1.2$ and $3.3 \pm 0.8$ days, respectively) and 20 of 26 control and 7 of 30 treated heifers were diagnosed pregnant 28 days after artificial insemination $(P<0.01)$. In Expt 2 , on the first day of dominance of the second dominant follicle, heifers received either a $\mathrm{PGF}_{2 \alpha}$ analogue alone (controls; $n=18$ ), or prostaglandin and a norgestomet implant for $6(\mathrm{~T} 6 ; n=19)$ or 10 days $(\mathrm{T} 10 ; n=20)$. Increases in the duration of dominance of the second dominant follicle (controls, $4.1 \pm 0.2$ days; T6, $8.6 \pm 0.2$ days; T10, $12.1 \pm 0.2$ days; $P<0.05$ ) resulted in a decrease in pregnancy rate (controls, 14 of 16; T6, 11 of 19; T10, 0 of $13 ; P \leq 0.05$ ). Progesterone concentrations on days 7 and 12 and the area of luteal tissue on day 12 after artificial insemination were not different $(P>0.05)$ between treatments. It is concluded that $(I)$ treatment with a synthetic progestagen towards the end of the luteal phase causes a variable extension of the period of dominance of the ovulatory follicle with a significant reduction in pregnancy rate, (2) the persistent dominant follicle can ovulate and form a functional corpus luteum, and (3) the pregnancy rate is sequentially decreased as the duration of dominance increases from 4 to 8 days, and is further significantly reduced if the duration of dominance exceeds 10 days.
\end{abstract}

\section{Introduction}

The oestrous response and fertility in cattle that have been given progestagens to synchronize oestrus and ovulation are influenced by the duration of progestagen treatment and the stage of the cycle at which treatment is initiated. Long treatments (> 12 days) and those started late in the oestrous cycle increase the oestrous response, but decrease pregnancy rates (e.g. using progesterone: Roche, 1974a, b, 1978; or synthetic progestagens: Beal et al., 1988; Brink and Kiracofe, 1988). Short-term progestagen treatments necessitate the use of a luteolytic agent and can lead to lowered or variable pregnancy rates (Brown et al., 1988; Favero et al., 1988); higher conception rates can be achieved by increasing the concentration of progestagen during synchronization of oestrus and ovulation (Wehrman et al., 1993).

It is now clear that successful synchronization of oestrus requires not only the control of luteal lifespan but also the presence of a functionally normal dominant follicle at the end of the treatment. During the oestrous cycle in cattle, there are

Received 10 February 1994 one or two periods of growth, selection, dominance and atresia of anovulatory dominant follicles before the ovulatory dominant follicle emerges at about the time of luteolysis (Ireland and Roche, 1987; Savio et al., 1988; Sirois and Fortune, 1988; Ginther et al., 1989). The turnover of dominant follicles during the cycle and early pregnancy is related to luteal progesterone concentrations (Bergfelt et al., 1991) and can be artificially maintained by administering luteal concentrations of progesterone after endogenous luteolysis (Sirois and Fortune, 1990; Adams et al., 1992). However, subluteal progesterone concentrations ( $1-2 \mathrm{ng} \mathrm{ml}^{-1}$ ) extend the period of dominance of the dominant follicle (Sirois and Fortune, 1990; Adams et al., 1992; Savio et al., 1992). Such concentrations of progesterone and, similarly, treatment with the synthetic progestagen norgestomet after luteolysis result in an increase in the frequency of $\mathrm{LH}$ pulses and oestradiol concentrations (Roberson et al., 1989; Kojima et al., 1992). Thus, the extension of the period of dominance of the ovulatory follicle (persistence) in the absence of a functional corpus luteum occurs in association with an increase in LH pulse frequency. However, LH pulsatile secretion never reaches follicular-phase-type frequencies that are necessary for the final maturation of the preovulatory 
follicle and ovulation (Rahe et al., 1980; Cupp et al., 1992; Savio et al., 1993; Stock and Fortune, 1993).

The period of dominance of the persistent follicle seems to depend on the timing of luteolysis (endogenous or exogenously induced) and on the duration of progestagen treatment. Only one study has measured the dominance phase of the ovulatory follicle and showed that a longer dominance phase can lead to reduced fertility (Stock and Fortune, 1993); however, the criteria for defining the dominance phase were not given and only a small number of heifers was involved. Induction of persistence of the first dominant follicle results in a significant drop in pregnancy rate in a large number of dairy heifers (Savio et al., 1992) and beef cows and heifers (Sanchez et al., 1993). However, the duration of dominance and ovulation of the persistent follicle were not monitored during either fertility trial, although the first study, using a similar treatment regimen, established the ovulatory ability of the persistent follicle in six cows.

Two experiments were therefore designed (1) to study the relationship between the duration of dominance of the ovulatory follicle and pregnancy rate and (2) to determine the ability of the persistent dominant follicle to ovulate and form a normal corpus luteum.

\section{Materials and Methods}

\section{Experiment 1}

Animals and treatments. The oestrous cycles of crossbred beef heifers, $320-420 \mathrm{~kg}$, were synchronized with two i.m. injections of $15 \mathrm{mg}$ Luprostiol, a $\mathrm{PGF}_{2 \alpha}$ analogue (PG; Prosolvin ${ }^{(\mathbb{B})}$, Intervet UK Ltd, Cambridge), 11 days apart. On day 16 of the subsequent cycle, heifers were blocked by breed and within block were randomly allocated to either an untreated control $(\mathrm{C}, n=30$ ) or treated group ( $\mathrm{T}, n=32$ ), where heifers were given an s.c. ear implant containing $3 \mathrm{mg}$ norgestomet (Crestar ${ }^{\circledR}$, Intervet UK Ltd) for 12 days. Detection of oestrus was carried out three times a day and heifers were artificially inseminated towards the end of the following oestrus with frozen-thawed semen from one bull by the same inseminator.

Ovarian ultrasonography. Growth and regression of individual follicles $>4 \mathrm{~mm}$ were monitored by ultrasonographic imaging with a $7.5 \mathrm{MHz}$ rectal transducer using a real-time, B-mode, linear array ultrasound scanner (Dynamic Imaging, Concept 500, Livingstone). Permanent records of ultrasound examinations were made using a Panasonic Video recorder. Fourteen control and 15 treated heifers were examined by ultrasound every other day from day 6-8 of the cycle to oestrus.

The definitions used in this study and measurements taken are as described by Ginther et al. (1989), with the following modifications. The day of emergence of a new cohort of follicles was the day on which the first follicle $>5 \mathrm{~mm}$ in diameter was detected in the cohort from which the subsequent dominant follicle developed. The first day of dominance of the second dominant follicle was defined by three criteria: (1) the first day that subordinates had stopped increasing in diameter (i.e. were static or regressing); (2) the time when the second dominant follicle was $\geqslant 8.5 \mathrm{~mm}$; and (3) the difference in size between the dominant follicle and the next largest subordinate was $>2 \mathrm{~mm}$ (not essential). The duration of dominance of the ovulatory follicle was the interval between the first day of dominance of the second or third dominant follicle (criteria used as in day 1 of the second dominant follicle) which was counted as day 1 , and oestrus (plus 1 day in Expt 1 to account for scanning every second day). Ovulation of the same follicle was confirmed in Expt 2 by the absence of the ultrasound image of that follicle 2 days after artificial insemination with a corpus luteum taking up the same position on the respective ovary on day 12 after artificial insemination. The maximum size of the second dominant follicle was measured as the largest diameter the second dominant follicle achieved during the scanning period. The size of the second dominant follicle at oestrus (oestrous size) was also measured. The growth rate of the second dominant follicle was calculated as the difference between the maximum size and the size on the first day of dominance, divided by the interval in days. Persistence of the dominant follicle was defined as the extended period of dominance of a follicle in progestagen-treated heifers compared with a similar follicle in control heifers. The diameters of the entire corpus luteum and the central cavity, if present, were measured in two planes and the average diameter and radius $(r)$ calculated. The area of the cross-sectional image was calculated from the formula $\pi r^{2}$, and the area of the central cavity was subtracted from the total area to obtain the area of luteal tissue.

All inseminated heifers were scanned approximately 14 days after artificial insemination for the presence of a corpus luteum and approximately 28 days after artificial insemination for pregnancy diagnosis. All heifers diagnosed as not pregnant were re-examined 1 week later to confirm the diagnosis.

\section{Experiment 2}

Animals and treatments. The oestrous cycles of crossbred beef heifers weighing approximately $350-450 \mathrm{~kg}$ were synchronized as in Expt 1. During the subsequent cycle, all heifers were examined by ultrasound for the emergence and selection of the second dominant follicle. On day 1 of the second dominant follicle, heifers were blocked by breed and day of cycle and within block were randomly allocated to three treatment groups, which received on that day (1) PG only (controls; $n=18$ ), (2) PG plus an s.c. norgestomet ear implant (Crestar ${ }^{\circledR}$, Intervet UK Ltd) for 6 days (T6; $n=19$ ) and (3) PG plus an s.c. norgestomet ear implant for 10 days (T10; $n=20$ ). One T10 heifer had to be excluded before implant removal for management reasons; her follicular data up to day 1 of the second dominant follicle were included in the statistical analysis. Detection of oestrus was carried out four times daily following PG administration (controls) or implant removal (T6 and $\mathrm{T} 10$ ), and heifers were inseminated during oestrus with frozen-thawed semen from one bull by the same inseminator.

Ovarian ultrasonography. Ultrasound examinations, as described for Expt 1, were carried out on days 8 and 10 of the oestrous cycle and subsequently on a daily basis until oestrus in control heifers and for 3 days after PG administration to treated heifers. Thereafter, both T6 and T10 heifers were 
scanned every second day until implant removal and again daily until oestrus. Inseminated heifers were scanned 2 and 12 days after artificial insemination to confirm ovulation and determine the area of luteal tissue and luteal cavity, if present, and then 30-35 days after artificial insemination for pregnancy diagnosis. Heifers diagnosed as not pregnant were re-examined 2 weeks later to confirm the diagnosis.

Collection of blood samples. Blood samples were collected via jugular venepuncture to determine serum progesterone concentrations (1) on the day of PG administration and daily for three further days to confirm the regression of the corpus luteum and (2) on days 7,12 and 17 after artificial insemination. Samples were kept at $4^{\circ} \mathrm{C}$ for $24 \mathrm{~h}$, and centrifuged at $1200 \mathrm{~g}$ for $20 \mathrm{~min}$; serum was then decanted and stored at $-20^{\circ} \mathrm{C}$ until assayed for progesterone (Ronayne and Hynes, 1990). Mean intra-assay $(n=24)$ and interassay $(n=5)$ coefficients of variation for a low $\left(0.82 \pm 0.02 \mathrm{ng} \mathrm{ml}^{-1}\right)$ and high (2.44 $\pm 0.05 \mathrm{ng} \mathrm{ml}^{-1}$ ) serum sample were 5.8 and $9.2 \%$ (low) and 7.5 and $6.8 \%$ (high), respectively. The sensitivity of the assay was $0.05 \mathrm{ng} \mathrm{ml}^{-1}$.

\section{Statistical analyses}

Analysis of variance was performed on data from both experiments. As there were no interactions between day of cycle at treatment initiation (Expt 2) or breed (Expts 1 and 2) and treatments, data relating to interoestrous intervals, and follicular and luteal tissue parameters were analysed by onefactor analysis of variance. Repeated-measures ANOVA was used to examine a time by treatment interaction of progesterone values on days 7, 12 and 17 after artificial insemination. The treatment effect was subsequently analysed by one-factor analysis of variance at each time point. Oestrous responses, the number of regressing or static ovulatory follicles at oestrus, and the pregnancy rate were compared using chi-squared analysis.

\section{Results}

\section{Experiment 1}

Oestrous response and interoestrous intervals. In control heifers 26 of 30 were detected in oestrus between days 19 and 24 of the cycle, while 30 of 32 treated heifers were in oestrus within $56 \mathrm{~h}$ of implant withdrawal (29 and 30 days after the previous oestrus). Of the two treated heifers not detected in oestrus, one ovulated during treatment, while the other developed a cyst $>30 \mathrm{~mm}$ in diameter and did not ovulate during the experiment. Only heifers showing oestrus were included in the statistical analysis. Control and treated heifers differed $(P<0.01)$ in their interoestrous interval $(20.9 \pm 0.3$ and $29.4 \pm 0.1$ days, respectively).

Examination of ovaries. The growth of dominant follicles in a representative treated and untreated heifer with either two or three dominant follicles per cycle is shown (Fig. 1). There was no difference $(P>0.05)$ between treatments in the proportion of heifers ovulating the second or third dominant follicle. In one of the treated heifers, emergence of a fourth wave occurred 1 day before implant removal with a fourth dominant follicle developing. The mean duration of dominance of the ovulatory follicle was prolonged $(P<0.05)$ in treated heifers compared with controls, ranging from $2.1 \pm 0.3$ days in control heifers with three waves of follicular development to $16.5 \pm 0.9$ in treated heifers with two waves (Table 1).

All 56 inseminated heifers had a corpus luteum on ultrasonic examination approximately 14 days after artificial insemination. This corpus luteum was on the ovary on which the ovulatory follicle had been 1 day before or at oestrus in the 29 scanned heifers.

Pregnancy rate. The pregnancy rate was lower $(P<0.01)$ in treated heifers ( 7 of $30 ; 23 \%$ ) than in controls ( 20 of $26 ; 77 \%$ ).

\section{Experiment 2}

Oestrous response and interoestrous intervals. All T6 heifers were observed in oestrus within 2 days of implant removal. One control heifer ovulated the second dominant follicle 4 days after PG treatment without being detected in oestrus. Similarly, ovulation of the second dominant follicle with no overt oestrous behaviour occurred in two T10 heifers, in one case 2 days after PG treatment and implant insertion and in the other instance 1 day after implant removal. These three heifers contributed only to data relating to the characteristics of the second wave of follicular growth and day 1 of the second dominant follicle. Another T10 heifer developed a cyst after implant removal and was excluded from all statistical analyses. The interoestrous interval was different $(P<0.05)$ between control, T6 and T10 heifers (16.6 $\pm 0.4,20.7 \pm 0.3$ and $25.3 \pm 0.4$ days, respectively). Synchrony of oestrus onset was similar $(P>0.05)$ in all three treatment groups with 15 of 17 control heifers in standing oestrus on the second or third day after PG treatment and 19 of 19 T6 and 15 of 16 T10 heifers detected in oestrus on the first or second day after implant removal. One T10 heifer did not show oestrus until 4 days after treatment withdrawal, and oestrus did not occur until 5 days after PG administration in two control heifers.

Examination of ovaries. All T6 heifers ovulated the second dominant follicle. In one of the control heifers a third dominant follicle developed after PG treatment and ovulated. In two T10 heifers a third dominant follicle developed after treatment initiation and became persistent, while in one T10 animal a third dominant follicle developed I day after implant removal and ovulated. Emergence of a new cohort of follicles during persistence of the second dominant follicle was observed in two more T10 heifers: in one case this happened 7 days after treatment initiation, and the new dominant follicle developed into a cyst; in the other instance, emergence occurred on the day of implant removal; however, the second dominant follicle still ovulated. Data obtained from heifers ovulating the third dominant follicle were excluded from the statistical analysis of ultrasound measurements of the second dominant follicle 

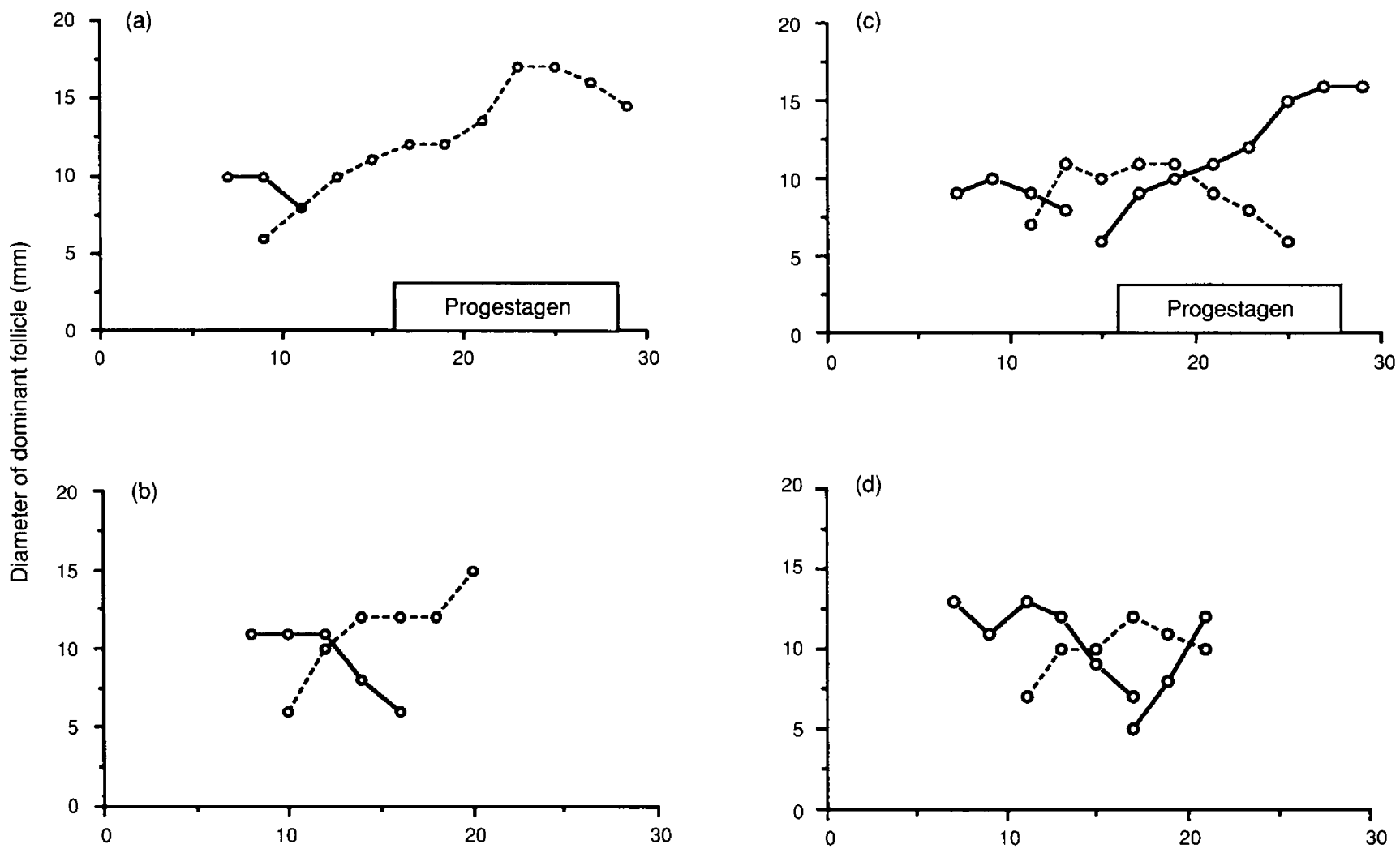

Fig. 1. Follicular turnover during the oestrous cycle of four representative heifers scanned until oestrus with (a, b) two or (c, d) three dominant follicles. Heifers were either $(b, d)$ untreated during the oestrous cycle or $(a, c)$ treated with a synthetic progestagen for 12 days starting on day 16 of the cycle (Expt 1).

(Table 2) and pregnancy rate after ovulation of the second dominant follicle.

There was no difference $(P>0.05)$ in the day of cohort emergence, day 1 of the second dominant follicle (range: days 11-17), and size on day 1 of the second dominant follicle (range: $8.5-11.5 \mathrm{~mm}$ ) between heifers assigned to the three

Table 1. Mean ( \pm SEM) duration of dominance of the ovulatory follicle in beef heifers examined by ultrasound scanning every other day, with two or three dominant follicles developing during the oestrous cycle (two- and three-wave heifers); heifers were left untreated for one oestrous cycle (control) or given a synthetic progestagen for 12 days starting on day 16 of the cycle (Expt 1)

\begin{tabular}{lcc}
\hline $\begin{array}{l}\text { Duration of dominance } \\
\text { (days) }\end{array}$ & $\begin{array}{c}\text { Control heifers } \\
(n=14)\end{array}$ & $\begin{array}{c}\text { Treated heifers } \\
(n=15)\end{array}$ \\
\hline Overall & $3.3 \pm 0.8^{\mathrm{a}}$ & $10.8 \pm 1.2^{\mathrm{b}}$ \\
Two-wave heifers $(n=4)$ & $6.3 \pm 2.2^{\mathrm{ax}}$ & $16.5 \pm 0.9^{\mathrm{bx}}$ \\
Three-wave heifers $(n=10)$ & $2.1 \pm 0.3^{\text {ay }}$ & $9.5 \pm 0.9^{\mathrm{by}}$
\end{tabular}

${ }^{a b}$ Means within a row with different superscripts are significantly different $(P<0.05)$.

${ }^{x y}$ Means within a column with different superscripts are significantly different $(P<0.05)$. treatment groups. The maximum diameter and the size of the second dominant follicle at oestrus was greater $(P<0.05)$ in T6 and T10 heifers compared with controls. There was a higher $(P=0.07)$ proportion of static or regressing ovulatory follicles at oestrus in T10 compared with T6 heifers. The duration of dominance of the second dominant follicle at oestrus was shortest in control heifers, increased in T6 and was longest in T10 heifers $(P<0.05 ;$ Table 2$)$. Figure 2 shows the mean growth of the second dominant follicle during its period of dominance in heifers undergoing all three treatments. All inseminated heifers had ovulated the largest follicle observed during oestrus when examined on day 2 after artificial insemination; the corpus luteum present on day 12 after artificial insemination was on the ovary on which the ovulatory follicle had been located in all heifers.

Serum progesterone concentrations on day 7 and day 12 after artificial insemination were not different $(P>0.05)$ between control, T6 and T10 heifers ovulating the second or third dominant follicle, or between heifers subsequently diagnosed as pregnant and not pregnant. A significant $(P \leq 0.02)$ time by treatment interaction was seen on day 17 after artificial insemination; a greater number of T10 heifers was undergoing luteolysis, which lowered $(P<0.05)$ mean progesterone concentrations when compared with control or T6 heifers. This was also seen in the group of heifers subsequently diagnosed as not pregnant (Tables 3 and 4 ). 
Table 2. Ultrasound measurements (means \pm SEM) of the second follicular wave and the second dominant follicle (DF) (i.e. ovulatory follicle) in beef heifers treated with prostaglandin analogue (PG) on the first day of dominance of the second dominant follicle (day 1 of DF2; control) or with PG and a synthetic progestagen for 6 (T6) or 10 (T10) days (Expt 2)

\begin{tabular}{|c|c|c|c|}
\hline Ultrasound parameters & Control & T6 & T10 \\
\hline \multicolumn{4}{|l|}{ Characteristics of the second wave and day 1 of DF2 } \\
\hline Wave emergence (day of cycle) & $11.0 \pm 0.3^{\mathrm{a}}$ & $10.4 \pm 0.6^{\mathrm{a}}$ & $10.8 \pm 0.3^{\mathrm{a}}$ \\
\hline Day 1 of DF2 (day of cycle) & $13.4 \pm 0.3^{\mathrm{a}}$ & $13.4 \pm 0.3^{\mathrm{a}}$ & $13.4 \pm 0.3^{\mathrm{a}}$ \\
\hline Interval from wave emergence to day 1 of DF2 (days) & $2.4 \pm 0.2^{\mathrm{a}}$ & $2.5 \pm 0.3^{\mathrm{a}}$ & $2.7 \pm 0.2^{a}$ \\
\hline Size on day 1 of DF2 (mm) & $9.7 \pm 0.2^{\mathrm{a}}$ & $9.7 \pm 0.2^{\mathrm{a}}$ & $9.7 \pm 0.2^{\mathrm{a}}$ \\
\hline \multicolumn{4}{|l|}{ Maximum size and associated parameters DF2 } \\
\hline Maximum size (mm) & $12.8 \pm 0.4^{a}$ & $17.3 \pm 0.5^{\mathrm{b}}$ & $20.8 \pm 0.7^{\mathrm{c}}$ \\
\hline Day of maximum size (day of cycle) & $16.2 \pm 0.4^{\mathrm{a}}$ & $20.3 \pm 0.3^{b}$ & $24.2 \pm 0.4^{c}$ \\
\hline Interval from day 1 of DF2 to maximum size (days) & $2.7 \pm 0.3^{\mathrm{a}}$ & $7.1 \pm 0.2^{b}$ & $10.6 \pm 0.2^{\mathrm{c}}$ \\
\hline Growth rate from day 1 of $\mathrm{DF} 2$ to maximum size $\left(\mathrm{mm}\right.$ day $\left.{ }^{-1}\right)$ & $1.2 \pm 0.2^{\mathrm{a}}$ & $1.1 \pm 0.1^{\mathrm{a}}$ & $1.0 \pm 0.1^{\mathrm{a}}$ \\
\hline \multicolumn{4}{|l|}{ Size of DF2 relating to implant removal and oestrus } \\
\hline Size at implant removal $(\mathrm{mm})$ & & $15.7 \pm 0.4^{\mathrm{a}}$ & $19.5 \pm 0.7^{b}$ \\
\hline Size at oestrus $(\mathrm{mm})$ & $12.7 \pm 0.4^{\mathrm{a}}$ & $17.2 \pm 0.5^{b}$ & $20.1 \pm 0.7^{c}$ \\
\hline Number of regressing or static ovulatory follicles at oestrus & $4 / 15^{\text {de }}$ & $4 / 18^{\mathrm{d}}$ & $7 / 13^{e}$ \\
\hline \multicolumn{4}{|l|}{ Duration of dominance of DF2 at oestrus (days) } \\
\hline & $4.1 \pm 0.2^{\mathrm{a}}$ & $8.6 \pm 0.2^{b}$ & $12.1 \pm 0.2^{c}$ \\
\hline
\end{tabular}

\footnotetext{
${ }^{\text {abc }}$ Means within a row with different superscripts are significantly different $(P<0.05)$.

${ }^{\text {de }}$ Means within a row with different superscripts are significantly different $(P=0.07)$.
}

There were no differences $(P>0.05)$ in the area of luteal tissue or the area of the central cavity between control, T6 and T10 heifers or pregnant and non-pregnant heifers (Tables 3 and 4).

Pregnancy rate. The pregnancy rate differed $(P \leq 0.05)$ between control (14 of 16), T6 (11 of 19) and T10 (0 of 13) heifers ovulating the second dominant follicle. When related to the duration of dominance of the ovulatory follicle (second or third dominant follicle), 15 of $17(88 \%)$ heifers with a duration of dominance of the ovulatory follicle of 1-4 days and 12 of 19 $(63 \%)$ heifers with a duration of dominance of the ovulatory follicle of $7-10$ days became pregnant $(P=0.08)$. Compared with these ratios, none of the 16 heifers in which the duration of dominance of the ovulatory follicle exceeded 10 days (11-13 days) was pregnant $(P<0.01)$.

\section{Discussion}

This study demonstrates the relationship between the duration of dominance of the ovulatory follicle and subsequent fertility, by treating beef heifers with the synthetic progestagen norgestomet after induced luteolysis and thus preventing atresia or ovulation of the second or third dominant follicle during the oestrous cycle. Although earlier studies showed a reduction in pregnancy rate after persistence of the first dominant follicle, they did not define the exact period of dominance of the ovulatory follicle, or monitor its ovulation and subsequent function of the corpus luteum (Savio et al., 1992; Sanchez et al., 1993).
To achieve persistence of a specific dominant follicle, luteolysis must be induced at a certain stage of follicular development of the respective follicle, rather than on a certain day of the cycle (Expt 2). Depending on the duration of growth and, thus, on the period of dominance, the persistent dominant follicle grows to a larger maximum and preovulatory size than its unmanipulated counterpart (Expt 2), with accompanying higher oestradiol concentrations (Sirois and Fortune, 1990; Savio et al., 1992, 1993; Stock and Fortune, 1993). The extended growth phase leads to a higher proportion of persistent follicles entering the plateau/regression phase once the period of dominance exceeds 10 days. Long persistence of a dominant follicle could possibly predispose it to cystic degeneration, as one cyst was detected in both Expts 1 and 2, and was also reported by Sirois and Fortune (1990). Individual differences either in the pattern of progestagen release or in the response of the heifer to a certain concentration of progestagen in the blood possibly shorten (with the emergence of a new wave of growth) or prolong the dominance period of persistent follicles.

Luteal progesterone concentrations, via their negative feedback on the LH pulse frequency (Ireland and Roche, 1981, 1982; Price and Webb, 1988) and its effect on follicular growth and oestradiol production (Glencross, 1987; Adams et al., 1992; Burke et al., 1994), are responsible for the turnover of dominant follicles during the cycle and early pregnancy (Bergfelt et al., 1991; Adams et al., 1992). Subluteal progesterone concentrations (1-2 $\mathrm{ng} \mathrm{ml}^{-1}$ ) or treatment with norgestomet after luteolysis will block turnover (Sirois and Fortune, 1990; Adams et al., 1992; Cupp et al., 1992; Savio et al., 1993; Expts 1 and 2), increase oestradiol concentrations and LH pulse frequency 

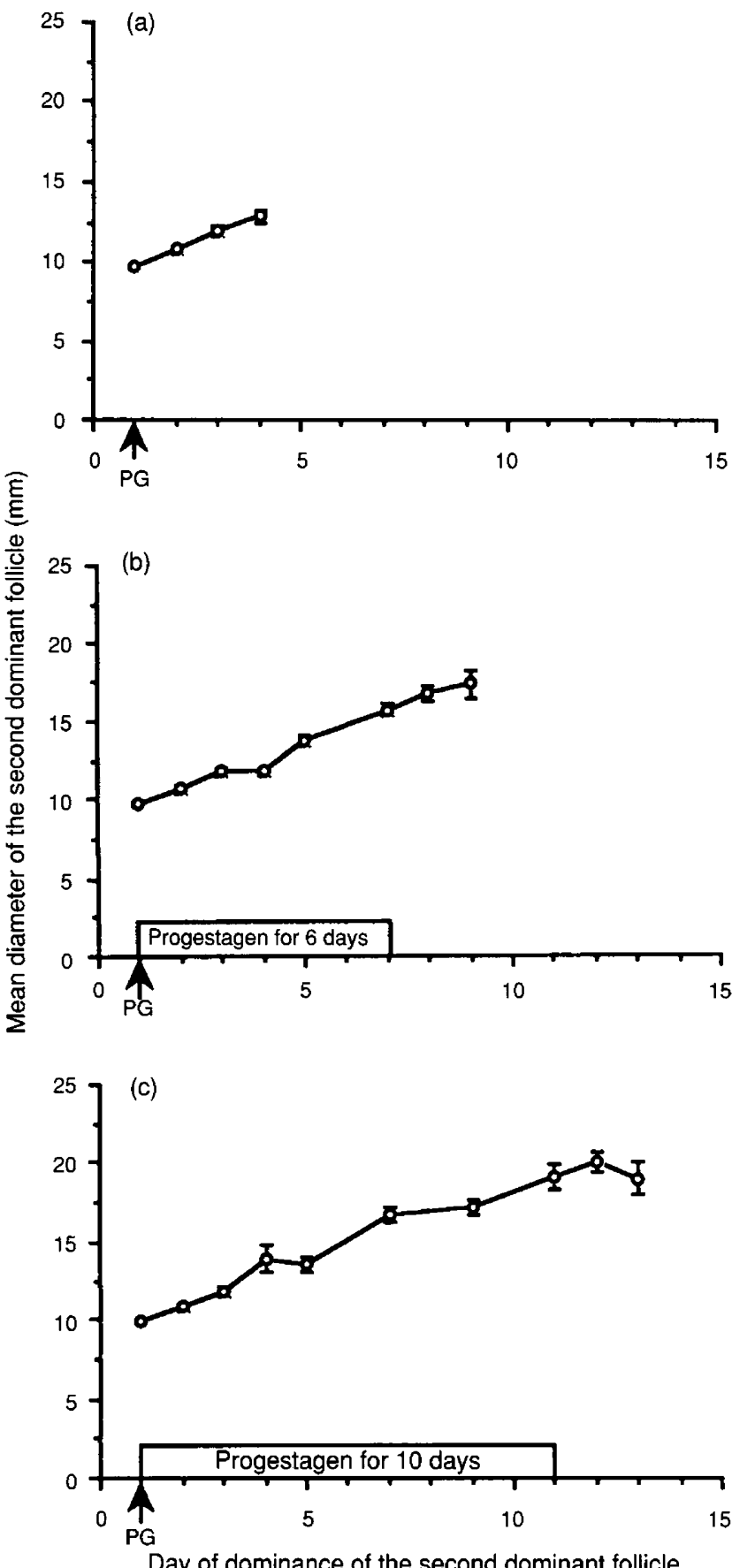

Fig. 2. Mean diameter ( \pm SEM) of the second dominant follicle from the first day of dominance to oestrus in heifers treated with either (a) prostaglandin (PG) alone $(n=16)$ or PG and a synthetic progestagen for (b) 6 days $(n=19)$ or (c) 10 days $(n=13)$ (Expt 2).

(Kojima et al., 1992), and cause a faster and more precise onset of the preovulatory LH surge and oestrus after withdrawal of treatment (Fogwell et al, 1986; Roberson et al., 1989; Expt 1). Additional progestagen reduces the LH pulse frequency and causes atresia of the persistent follicle, whereas follicular phase LH pulsatility occurs only after withdrawal of treatment (Cupp et al., 1992; Savio et al., 1993; Stock and Fortune, 1993).
Treatment with norgestomet prevents the oestradiolinduced LH rise in ovariectomized heifers (Bolt et al., 1990) and also ovulation in all but two cases in Expts $I$ and 2. The corpus luteum that formed after the ovulation of persistent follicles had a normal lifespan (Savio et al., 1992) and progesterone concentrations in six heifers between days 2 and 14 after artificial insemination (Stock and Fortune, 1993). Although several authors monitored the persistent follicle until ovulation (Rajamahendran and Taylor, 1991; Savio et al., 1993; Stock and Fortune, 1993; Taylor et al., 1993), its ovulatory ability has not previously been related to withdrawal of treatment or the exact period of dominance. Results from Expt 2 show that even follicles with a very long duration of dominance ovulate and form corpora lutea of normal dimensions and progesterone secretory capacity.

The timing of luteolysis in relation to the stage of follicular development of the respective dominant follicle is crucial for optimizing synchrony of ovulation (Macmillan and Henderson, 1983, 1984). Equally high oestrous synchrony was achieved after luteolysis on the first day of dominance of the dominant follicle, or after maintenance of dominant follicles in an extended growth phase (independent of actual duration of growth and size) by treatment with a progestagen.

Prolonged growth and dominance of the ovulatory follicle result in lowered fertility in both experiments. Other studies reported either a reduction or no differences in pregnancy rate after persistence of the ovulatory follicle (Rajamahendran and Taylor, 1991; Stock and Fortune, 1993; Taylor et al., 1993); apart from the small number of heifers used, the differing results could be due to the variation in the duration of dominance of the ovulatory follicle achieved by different treatment regimens. However, it can be concluded that longterm progestagen treatments or those initiated at about the time of endogenous luteolysis will lead to the persistence of the ovulatory follicle with a concomitant drop in pregnancy rates. Persistence of the first dominant follicle results in a significant decrease in the pregnancy rate from $65 \%$ to $37 \%$ in dairy heifers (Savio et al., 1992) and from $75 \%$ to $40 \%$ in beef cows and heifers (Sanchez et al., 1993). However, as already stated, none of these studies monitored persistence and ovulation of the first dominant follicle, nor the actual duration of dominance during the fertility trial. Data from Expt 2 demonstrate clearly that fertility depends on the duration of the dominance period of the ovulatory follicle.

As the reduced fertility is not a result of lack of ovulation or subsequent luteal function, three main factors could be responsible for the decrease in pregnancy rate in cattle after ovulation of a follicle with a long duration of dominance. Increased oestradiol production over an extended period of dominance might change the intrafollicular, oviductal and uterine environment, causing accelerated ovum transport or early embryonic death (Hafez et al., 1963; Butcher and Pope, 1979). Intrafollicular changes during such prolonged growth could possibly influence the oocyte within the persistent follicle and, after ovulation, render it incapable of fertilization or disturb early embryonic development. In particular, the slowly increasing $\mathrm{LH}$ pulse frequency might dissociate the resumption of meiosis from the LH surge and ovulation, leading to ovulation of an excessively aged oocyte (Mattheij et al., 1994). However, progestagen treatments lower sperm 
Table 3. Luteal parameters (mean \pm SEM) 7,12 and 17 days after artificial insemination (AI) in beef heifers treated with prostaglandin on the first day of dominance of the second dominant follicle (control) or with prostaglandin and a synthetic progestagen for 6 (T6) or 10 (T10) days (Expt 2)

\begin{tabular}{|c|c|c|c|}
\hline Luteal parameters & Control & T6 & T10 \\
\hline \multicolumn{4}{|c|}{ Progesterone concentrations ( $\mathrm{ng} \mathrm{ml}^{-1}$ ) } \\
\hline Day 7 after $\mathrm{AI}$ & $2.3 \pm 0.3^{\mathrm{a}}$ & $2.6 \pm 0.3^{\mathrm{a}}$ & $2.9 \pm 0.3^{2}$ \\
\hline Day 12 after $\mathrm{AI}$ & $3.3 \pm 0.2^{\mathrm{a}}$ & $2.9 \pm 0.2^{a}$ & $3.0 \pm 0.2^{\circ}$ \\
\hline Day 17 after $\mathrm{Al}$ & $3.0 \pm 0.3^{\mathrm{a}}$ & $2.8 \pm 0.3^{\mathrm{a}}$ & $1.8 \pm 0.3^{\mathrm{b}}$ \\
\hline \multicolumn{4}{|c|}{ Corpus luteum measurement on day 12 after AI } \\
\hline Area of luteal tissue $\left(\mathrm{mm}^{2}\right)$ & $406.1 \pm 34.3^{\mathrm{a}}$ & $435.5 \pm 20.8^{a}$ & $402.7 \pm 21.7^{\circ}$ \\
\hline Area of central cavity $\left(\mathrm{mm}^{2}\right)$ & $29.4 \pm 14.6^{a}$ & $108.5 \pm 35.1^{\mathrm{a}}$ & $130.3 \pm 45.0^{\circ}$ \\
\hline
\end{tabular}

${ }^{a b}$ Means within a row with different superscripts are significantly different $(P<0.05)$.

Table 4. Luteal parameters (mean \pm SEM) 7, 12 and 17 days after artificial insemination (AI) in beef heifers diagnosed by ultrasound as pregnant or not pregnant 30-35 days after AI (Expt 2)

\begin{tabular}{lcc}
\hline Luteal parameters & $\begin{array}{c}\text { Pregnant } \\
(n=25-26)\end{array}$ & $\begin{array}{c}\text { Not pregnant } \\
(n=23-25)\end{array}$ \\
\hline
\end{tabular}

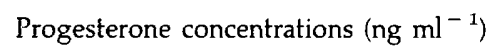

$\begin{array}{lll}\text { Day } 7 \text { after AI } & 2.4 \pm 0.2^{\mathrm{a}} & 2.8 \pm 0.3^{\mathrm{a}} \\ \text { Day } 12 \text { after AI } & 3.2 \pm 0.2^{\mathrm{a}} & 2.9 \pm 0.1^{\mathrm{a}} \\ \text { Day } 17 \text { after AI } & 3.3 \pm 0.2^{\mathrm{a}} & 1.8 \pm 0.2^{\mathrm{b}}\end{array}$

Corpus luteum measurement on day 12 after $\mathrm{AI}$
Area of luteal tissue $\left(\mathrm{mm}^{2}\right)$
$414.8 \pm 21.4^{\mathrm{a}}$
$417.5 \pm 20.2^{\mathrm{a}}$
Area of central cavity $\left(\mathrm{mm}^{2}\right)$
$60.7 \pm 18.9^{\mathrm{a}}$
$122.8 \pm 36.0^{\mathrm{a}}$

${ }^{\mathrm{ab}}$ Means within a row with different superscripts are significantly different $(P<0.05)$.

numbers in the vagina, uterus and oviduct after artificial insemination and increase sperm breakage in ewes (Hawk, 1971; Hawk and Conley, 1971). Early fertilization studies using the synthetic progestagen melengestrol acetate (MGA) showed reduced ova recovery rates and an indication of a higher incidence of fertilization failure with faster transport of eggs through the oviduct in MGA-treated beef heifers, although the response varied with the stage of cycle at which treatment began and the dose of progestagen used (Hill et al., 1971; Reed and Rich, 1972). Despite the development of abnormally large hyperplastic follicles during longterm MGA treatments (Guthrie et al., 1970), fertilized ova were recovered after natural mating (Lamond et al., 1971). Future research should concentrate on fertilization studies after the ovulation of persistent dominant follicles, in relation to the duration of progestagen treatment and dominance, noting differences in the stage of the persistent follicle (growing, static or regressing) at ovulation.

The present study demonstrates for the first time the relationship between the duration of dominance of the ovulatory follicle and the subsequent fertility in heifers given norgestomet implants to control oestrus and ovulation. A high pregnancy rate was achieved when the period of dominance was restricted to $1-4$ days, whereas dominance of $>10$ days was associated with no pregnancies. It can therefore be concluded that (1) the pregnancy rate decreases with the increase in the duration of dominance, and (2) the duration of dominance for optimum fertility is less than 8 days. This could have implications for the health of the ovulatory follicle and its oocyte in oestrous cycles with two dominant follicles, in which the dominance period of the ovulatory follicle (the second dominant follicle) possibly exceeds 6 days, and should be considered for future synchronization regimens after successful manipulation of luteolysis.

The authors wish to thank Kildangan Stud, Kildangan, Co. Kildare, Ireland for access to heifers, their maintenance and care, and BioResearch Ireland for financial support. They also thank C. Burke, D. O'Callaghan, M. A. Crowe, A. Donovan, P. Duffy, S. J. Sunderland and T. Sweeney for excellent assistance during the experiments and $\mathrm{N}$. Hynes for assistance in the hormone assays. They are grateful to Clonatec Ltd, Paris for providing the monoclonal progesterone antibody.

\section{References}

Adams GP, Matteri RL and Ginther OJ (1992) Effect of progesterone on ovarian follicles, emergence of follicular waves and circulating follicle-stimulating hormone in heifers Journal of Reproduction and Fertility $95627-640$

Beal WE, Chenault JR, Day ML and Corah LR (1988) Variation in conception rates following synchronization of estrus with melengestrol acetate and prostaglandin F-2a Journal of Animal Science 66 599-602

Bergfelt DR, Kastelic JP and Ginther OJ (1991) Continued periodic emergence of follicular waves in non-bred progesterone-treated heifers Animal Reproduction Science 24 193-204

Bolt DJ, Scott V and Kiracofe GH (1990) Plasma LH and FSH after estradiol, norgestomet and $\mathrm{Gn}-\mathrm{RH}$ treatment in ovariectomized beef heifers Animal Reproduction Science 23 263-271

Brink JT and Kiracofe GH (1988) Effect of estrous cycle stage at SynchroMate-B treatment on conception and time to estrus in cattle Theriogenology 29 513-518

Brown LN, Odde KG, King ME, LeFever DG and Neubauer CJ (1988) Comparison of melengestrol acetate-prostaglandin F-2a to Synchro-Mate-B for estrus synchronization in beef heifers Theriogenology $301-12$

Burke CR, Mihm M, Macmillan KL and Roche JF (1994) Some effects of prematurely elevated concentrations of progesterone on luteal and follicular characteristics during the oestrous cycle in heifers Animal Reproduction Science 35 27-39

Butcher RL and Pope RS (1979) Role of estrogen during prolonged estrous cycles of the rat on subsequent embryonic death or development Biology of Reproduction 21 491-495. 
Cupp A, Garcia-Winder M, Zamudio A, Mariscal V, Wehrman M, Kojima N Peters K, Bergfeld E, Hernandez P, Sanchez T, Kittok R and Kinder J (1992) Two concentrations of progesterone (P4) in circulation have a differential effect on pattern of ovarian follicular development in the cow Biology of Reproduction 46 (Supplement 1) 106 (Abstract)

Favero RJ, Faulkner DB and Kesler DJ (1988) Estrus synchronization in beef females with Synchro-Mate-B: efficacy and factors that restrict optimal pregnancy rates Theriogenology 29245

Fogwell RL, Kanyima BM, Villa-Godoy A, Enright WJ and Ireland JJ (1986) Enhanced precision of estrus and luteinizing hormone after progesterone and prostaglandin in heifers Journal of Dairy Science 69 2179-2185

Ginther OJ, Knopf I and Kastelic JP (1989) Composition and characteristics of follicular waves during the bovine oestrous cycle Animal Reproduction Science $20187-200$

Glencross RG (1987) Effect of pulsatile infusion of gonadotrophin-releasing hormone on plasma oestradiol-17 $\beta$ concentrations and follicular development during naturally and artificially maintained high levels of plasma progesterone in heifers Journal of Endocrinology 112 77-85

Guthrie HD, Lamond DR, Henricks DM and Dickey JF (1970) Ovarian follicular changes in heifers treated with melengestrol acetate Journal of Reproduction and Fertility 22 363-364

Hafez ESE, Sugie T and Gordon I (1963) Superovulation and related phenomena in the beef cow I. Superovulatory responses following PMS and HCG injections Journal of Reproduction and Fertility 5 359-379

Hawk HW (1971) Sperm destruction in the sheep vagina Journal of Animal Science 33255 (Abstract)

Hawk HW and Conley HH (1971) Sperm transport in ewes administered synthetic progestagen Joumal of Animal Science 33 255-256 (Abstract)

Hill JR, Jr, Lamond DR, Henricks DM, Dickey JF and Niswender GD (1971) The effect of melengestrol acetate (MGA) on ovarian function and fertilization in beef heifers Biology of Reproduction 4 16-22

Ireland JJ and Roche JF (1981) The differential effect of progesterone on concentrations of luteinizing hormone and follicle-stimulating hormone in heifers Endocrinology 108 568-572

Ireland JJ and Roche JF (1982) Effect of progesterone on basal LH and episodic LH and FSH secretion in heifers Journal of Reproduction and Fertility 64 295-302

Ireland JJ and Roche JF (1987) Hypotheses regarding development of dominant follicles during bovine oestrous cycles. In Follicular Growth and Ovulation Rate in Farm Animals, pp 1-17 Eds JF Roche and D O'Callaghan. Martinus Nijhoff Publishers, The Hague.

Kojima N, Stumpf TT, Cupp AS, Werth LA, Roberson MS, Wolfe MW, Kittok RJ and Kinder JE (1992) Exogenous progesterone and progestins as used in estrous synchrony regimens do not mimic the corpus luteum in regulation of luteinizing hormone and $17 \beta$-estradiol in circulation of cows Biology of Reproduction 47 1009-1017

Lamond DR, Dickey JF, Henricks DM, Hill JR and Leland TM (1971) Effect of a progestin on the bovine ovary Journal of Animal Science 33 77-82

Macmillan KL and Henderson HV (1983/1984) Analyses of the variation in the interval from an injection of prostaglandin $\mathrm{F}-2 \alpha$ to oestrus as a method of studying patterns of follicle development during dioestrus in dairy cows Animal Reproduction Science 6 245-254

Mattheij JAM, Swarts JJM, Hurks HMH and Mulder K (1994) Advancement of meiotic resumption in Graafian follicles by LH in relation to preovulatory ageing of rat oocytes Journal of Reproduction and Fertility 100 65-70
Price CA and Webb R (1988) Steroid control of gonadotropin secretion and ovarian function in heifers Endocrinology 122 2222-2231

Rahe CH, Owens RE, Fleeger JL, Newton HJ and Harms PG (1980) Pattern of plasma luteinizing hormone in the cyclic cow: dependence upon the period of the cycle Endocrinology 107 498-503

Rajamahendran $\mathbf{R}$ and Taylor C (1991) Follicular dynamics and temporal relationships among body temperature, oestrus, the surge of luteinizing hormone and ovulation in Holstein heifers treated with norgestomet Journal of Reproduction and Fertility 92 461-467

Reed TD and Rich TD (1972) Influence of MGA on cow fertility Journal of Animal Science 35 1123-1124 (Abstract)

Roberson MS, Wolfe MW, Stumpf TT, Kittok RJ and Kinder JE (1989) Luteinizing hormone secretion and corpus luteum function in cows receiving two levels of progesterone Biology of Reproduction 41 997-1003

Roche JF (1974a) Effect of short-term progesterone treatment on oestrous response and fertility in heifers Journal of Reproduction and Fertility $\mathbf{4 0}$ $433-440$

Roche JF (1974b) Synchronization of oestrus in heifers with implants of progesterone Journal of Reproduction and Fertility 41 337-344

Roche JF (1978) Control of oestrus in cattle using progesterone coils Animal Reproduction Science 1 145-154

Ronayne E and Hynes N (1990) Measurement of plasma progesterone concentrations by extraction and non-extraction radioimmunoassays Irish Journal of Agricultural Research 29 109-115

Sanchez T, Wehrman ME, Bergfeld EG, Peters KE, Kojima FN, Cupp AS, Mariscal V, Kittok RJ, Rasby RJ and Kinder JE (1993) Pregnancy rate is greater when the corpus luteum is present during the period of progestin treatment to synchronize time of estrus in cows and heifers Biology of Reproduction 49 1102-1107

Savio JD, Keenan L, Boland MP and Roche JF (1988) Pattern of growth of dominant follicles during the oestrous cycle in heifers Journal of Reproduction and Fertility $83663-671$

Savio JD, Thatcher WW, Morris GR, Entwistle K and Drost M (1992) Terminal follicular development and fertility in cattle is regulated by concentration of plasma progesterone Proceedings of the 12th International Congress on Animal Reproduction 2 999-1001

Savio JD, Thatcher WW, Badinga L, de la Sota RL and Wolfenson D (1993) Regulation of dominant follicle turnover during the oestrous cycle in cows Journal of Reproduction and Fertility 97 197-203

Sirois J and Fortune JE (1988) Ovarian follicular dynamics during the estrous cycle monitored by real-time ultrasonography Biology of Reproduction 39 308-317

Sirois J and Fortune JE (1990) Lengthening of the bovine estrous cycle with two levels of exogenous progesterone: a model for studying ovarian follicular dominance Endocrinology 127 916-925

Stock AE and Fortune JE (1993) Ovarian follicular dominance in cattle: relationship between prolonged growth of the ovulatory follicle and endocrine parameters Endocrinology 132 1108-1114

Taylor C, Rajamahendran R and Walton JS (1993) Ovarian follicular dynamics and plasma luteinizing hormone concentrations in norgestomet-treated heifers Animal Reproduction Science 32 173-184

Wehrman ME, Roberson MS, Cupp AS, Kojima FN, Stumpf TT, Werth LA, Wolfe MW, Kittok RJ and Kinder JE (1993) Increasing exogenous progesterone during synchronization of estrus decreases endogenous $17 \beta$-estradiol and increases conception in cows Biology of Reproduction $49214-220$ 